\title{
Trench and drilling investigation of the Median Tectonic Line in Shikoku, southwest Japan: implications for fault geometry
}

\author{
Masahiro Miyawaki ${ }^{1,2^{*}}$ and Arito Sakaguchi ${ }^{2}$
}

\begin{abstract}
The Median Tectonic Line (MTL) is a thousand-kilometer-long fault that extends across southwest Japan. Near the Nyugawa region of Shikoku, the MTL comprises (i) a low-angle inactive terrane boundary fault (the MTLTB) that divides the Jurassic and Cretaceous geological terranes, and (ii) a subparallel high-angle active fault zone (the MTLAFZ; Kawakami Fault). To better understand the relationship between the MTLTB and MTLAFZ fault traces, we exposed a ten-meter-long trench of approximately 2-m depth across the Kawakami Fault. We also drilled and cored five boreholes with lengths 80-330 m along a $100 \mathrm{~m}$ transect to understand the cross-cutting relationship between the MTL faults and to determine the fault plane geometries and their dipping values. The Kawakami Fault was found to be a high-angle $\left(>70^{\circ}\right)$ active fault exposed at the surface; however, it represents a non-vertical or listric fault that converges to the low-angle MTLTB fault dipping to the north at $30^{\circ}$. The Kawakami Fault was originally formed as a reverse fault, and subsequent dextral strike-slip displacement occurred along the same fault plane. Although the MTLTB is poorly oriented with respect to the regional stress field, it is capable of rupturing owing to its significantly weak interface; the properties of local faulted rock material are expected to play an important role in determining slip behavior.
\end{abstract}

Keywords: Median Tectonic Line, Active fault, Paleoseismology, Trench, Drilling, Seismic hazard

\section{Introduction}

In the continental crust, strike-slip faults such as the San Andreas Fault (Lawson 1895; Atwater 1970), North Anatolian Fault (Stein et al. 1997), Alpine Fault (Wellman and Willett 1942; Walcott 1998), and Wairarapa Fault (Rodgers and Little 2006; Little et al. 2009) represent the major loci of large and destructive earthquakes (>Mw 8.2) with long recurrence rates of 0.5 to 2 kiloyears, or even higher.

*Correspondence: masahiro_miyawaki@nsr.go.jp

${ }^{1}$ Regulatory Standard and Research Department, Secretariat

of Nuclear Regulation Authority (S/NRA/R), 1-9-9 Roppongi, Minato-ku,

Tokyo 106-8450, Japan

Full list of author information is available at the end of the article
The seismic potential of such faults is often inferred from indirect observations and theoretical considerations.

The Median Tectonic Line (MTL; Naumann 1886; Tsutsumi and Okada 1996; Goto 2018; Kubota et al. 2020) is a trench $1000 \mathrm{~km}$ in length parallel to a dextral strike-slip fault, dividing southwest Japan into outer and inner zones (Fig. 1a). The active fault of the MTL is characterized by clear lineaments, that are visible on satellite images and are known to slip dextrally at a maximum rate of $5-10 \mathrm{~mm} /$ year in Shikoku Island, thereby making it one of Japan's most active onshore faults with recurrence intervals of 0.6 to $>1.0$ kiloyears (Okada 1973; Tsutsumi and Okada 1996; Goto and Nakata 2000; Goto 2018). Trench surveys of active fault segments conducted at a few dozen sites along the MTL indicate strike-slip 


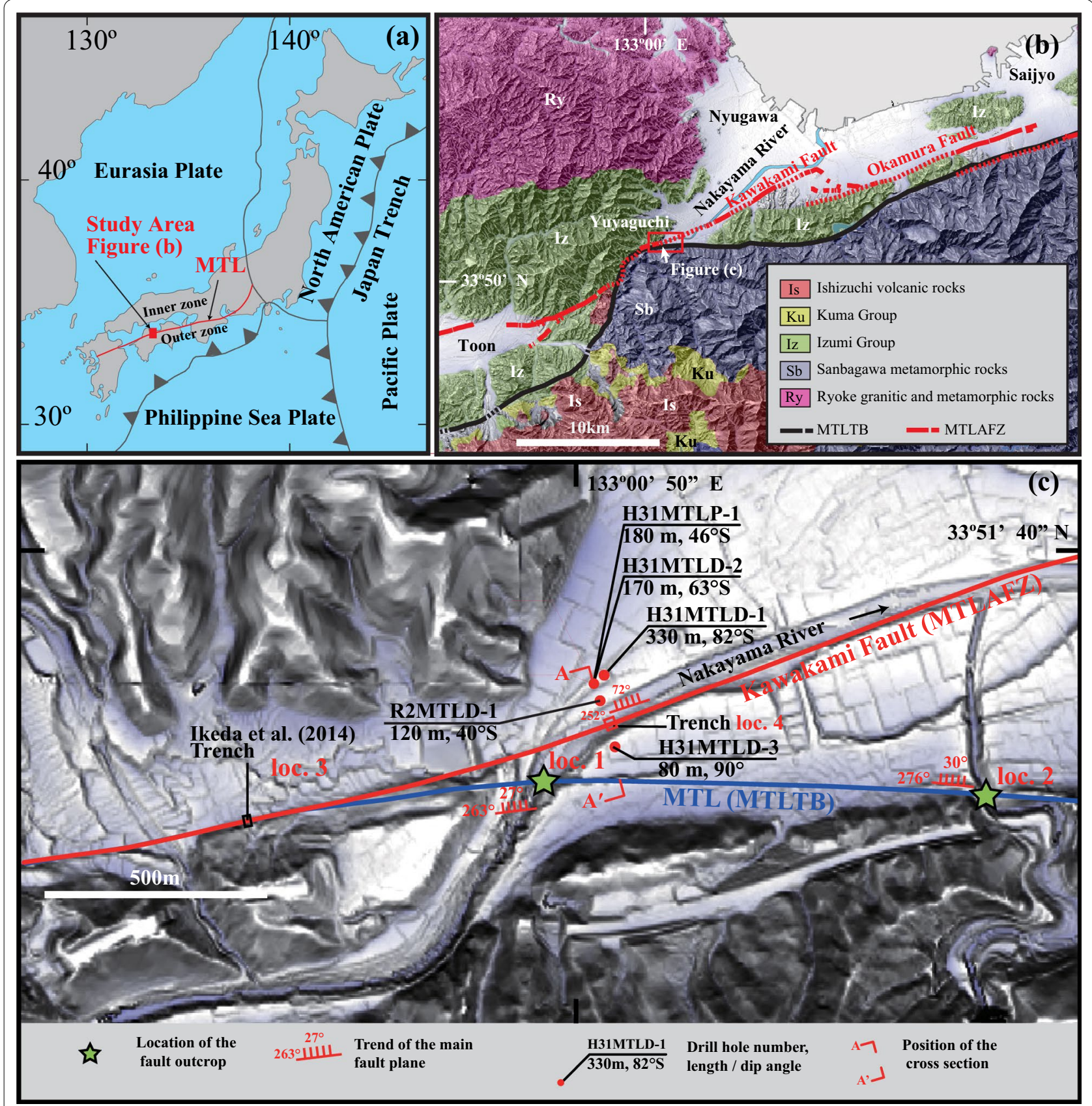

Fig. 1 Geological setting of the MTL and locations of the investigation sites. a The tectonic setting of the Japanese Islands; $\mathbf{b}$ geological map of the northwestern Shikoku Island; $\mathbf{c}$ locations of drilling and trench sites. The geological map was modified from a seamless digital geological map of Japan (1:200 000) edited by the Geological Survey of Japan (2017). Active fault data were compiled from Nakata et al. (1998), Goto et al. (1998), and Tsutsumi et al. (1998). The shaded relief map was created using a 5-m DEM obtained from the Geospatial Information Authority of Japan.

displacements, with a dip angle of more than $70^{\circ}$, predominantly in the Shikoku region (Tsutsumi et al. 1992; Okada and Tsutsumi 1997; Goto et al. 2001; Ikeda et al. 2012). Seismic reflection surveys image low-angle reflectors; these have been interpreted as fault planes by inferring that high-angle active faults, outcropping at the surface, root to low-angle older terrane boundary faults at depth (Yoshikawa et al. 1992; Ito et al. 1996; Sato et al. 2015; Iwata et al. 2020).

However, the results of seismic reflection surveys are unclear in terms of the relationship between high-angle faults at the surface and deeper low-angle 
terrane boundary faults. Since the frequency of seismicity along the MTL has remained low in recent times, it was not possible to accurately estimate the attitude of the fault plane based on information from aftershock distributions.

Therefore, it is difficult to infer the attitude of the subsurface fault from the attitude of the apparent fault on the surface. More than three million people live in Shikoku, and millions live in densely populated cities close to the MTL in Honshu. Knowledge of the seismic hazard posed by the MTL to people and infrastructure will help in making informed decisions to mitigate earthquake risks. In particular, evaluating the geometry of the MTL fault plane can influence seismic-hazard assessments of disaster distribution and earthquake magnitude. In this study, we describe the structure of the central segment of the MTL near Nyugawa resolved by shallow drilling and surface trenching.

\section{Geological settings}

The MTL has a long tectonic history since the Cretaceous, and has experienced several slip senses of dextral, sinistral, normal, and reverse faulting with changes in regional stress (e.g., Kobayashi 1941; Ichikawa 1980; Takagi and Shibata 1992; Aoya et al. 2013; Kubota et al. 2020). The current MTL displacement shows dextral movements in response to the oblique subduction of the Philippine Sea Plate (Nishimura et al. 2018). Active dextral MTL fault structures are typically observed on Shikoku (Okada 1970; Tsutsumi and Okada 1996; Goto and Nakata 2000). Detailed geological mapping (e.g.,Takahashi 1992; Kubota and Takeshita 2007; Shigematsu et al. 2012; Aoya et al. 2013) and seismic reflection surveys (e.g., Ito et al. 1996; Tsutsumi et al. 2007; Shigei et al. 2014) have distinguished the high-angle MTL active fault zone (MTLAFZ) from the low-angle inherited MTL geological terrane boundary fault (MTLTB). The MTLTB and the MTLAFZ run subparallel to each other in central Shikoku (Fig. 1b).

In the Shikoku region, the MTLTB juxtaposes the Cretaceous sediments of the Izumi Group in the north against the Cretaceous Sanbagawa metamorphic rocks in the south (Fig. 1b). The Miocene Ishizuchi volcanic rocks unconformably cover the Sanbagawa metamorphic rocks. Typical MTLTB outcrops, exposed at the Yuyaguchi site, are preserved as a national natural monument (location 1 in Fig. 1c). The trend of the fault is along the east-west direction with a dip angle of $27^{\circ}$ to the north. Andesite with a thickness of approximately $20 \mathrm{~m}$ intrudes along the fault and is generally brecciated by faulting (locations 1 and 2 in Fig. 1c). The K-Ar age of andesite is $21.1 \pm 1.2 \mathrm{Ma}$, which is consistent with the age of Ishizuchi volcanic rocks. The andesites are possibly related to volcanic activity in the Miocene (Tazaki et al. 1990). The MTLTB is assumed to be inactive because it does not offset Quaternary sediments and terrace surfaces (Nagai and Kondo 1972).

The MTLAFZ section in the study area is referred to as the Kawakami Fault (Okada 1973; Research Group for Active Faults of Japan 1991), which has developed at the hanging wall of the MTLTB. The Kawakami Fault, which strikes east-northeast, is subparallel to the MTLTB at a distance of $100 \mathrm{~m}$ and dips steeply $\left(60-72^{\circ}\right)$ northward (Fig. $1 \mathrm{~b}$ and c) at the trench site. The Kawakami Fault bounds the Pliocene-Pleistocene half-graben Okamura Group and the Cretaceous Izumi Group. The presence of slickensides and the asymmetric structure of the fault zone indicate predominant strike-slip movement at the latest slip surface (Kubota et al. 2020). Based on ${ }^{14} \mathrm{C}$ dating at the Kawakami Fault, the most recent seismic event was traced to the Keicho earthquake of 1596 (Ikeda et al. 2014, 2019).

\section{Trench and drilling investigations}

The Secretariat of the Nuclear Regulation Authority, Japan, has been conducting trenching and scientific drilling near Nyugawa Shikoku since 2017. The specifications of the trench excavation and the boreholes are listed in Table 1. In this study, one trench was exposed and five boreholes drilled along a $100-\mathrm{m}$ transect across the Kawakami Fault and the MTLTB (Fig. 1c). The trench was $10 \mathrm{~m}$ long and extended to a depth of approximately $2 \mathrm{~m}$ across the Kawakami Fault. Trenching was carried out to clarify only the attitude of the Kawakami Fault, and ${ }^{14} \mathrm{C}$ dating of exposed fluvial deposits was not undertaken as part of this study. The total length of the northernmost borehole (H31MTLD-1) was $330 \mathrm{~m}$ with an inclination of $82^{\circ}$ to the south; it was the longest of the five boreholes. H31MTLD-1 and the other boreholes H31MTLD-2 (170 m), H31MTLP-1 (180 m), and R2MTLD-1(120 m) penetrated both the Kawakami Fault and the MTLTB. The southernmost borehole (H31MTLD-3) was drilled vertically to a total length of $80 \mathrm{~m}$ to specifically target the MTLTB. Wireline logging was conducted in the longest borehole (H31MTLD-1), including measuring natural gamma rays, P-wave velocity, spontaneous potential, electric resistivity, and gamma-ray density. Observations using calipers and an acoustic borehole televiewer were also conducted. These wireline loggings and observations were made at all sections except those shallower than $50 \mathrm{~m}$ because of the casing. An optical borehole televiewer was also used in H31MTLD-2, H31MTLD-3, and R2MTLD-1 at each fault zone. All drill cores were recovered from sections below the casing. The fault rocks have been described in this study in accordance with 
Table 1 Specifications of the trench and the boreholes

\begin{tabular}{|c|c|c|c|c|c|c|}
\hline \multicolumn{7}{|c|}{ (a) Specification of the trench } \\
\hline \multirow[t]{2}{*}{ Location of bench mark } & & & \multicolumn{3}{|l|}{ North latitude } & $33^{\circ} 51^{\prime} 27.16653^{\prime \prime}$ \\
\hline & & & \multicolumn{2}{|l|}{ East longitude } & & $133^{\circ} 00^{\prime} 52.52249^{\prime \prime}$ \\
\hline \multicolumn{5}{|l|}{ Elevation of bench mark } & \multicolumn{2}{|c|}{$61.99 \mathrm{~m}$} \\
\hline \multicolumn{3}{|l|}{ Size of trench } & & & \multicolumn{2}{|c|}{$\begin{array}{l}\text { Length: } 10 \mathrm{~m} \text {, } \\
\text { width: } 5 \mathrm{~m} \text {, depth: } \\
1.5 \mathrm{~m} \sim 2 \mathrm{~m}\end{array}$} \\
\hline \multicolumn{7}{|c|}{ (b) Specification of boreholes } \\
\hline Borehole name & & H31MTLD-1 & H31MTLP-1 & H31MTLD-2 & R2MTLD-1 & H31MTLD-3 \\
\hline \multirow[t]{2}{*}{ Location } & North latitude & $33^{\circ} 51^{\prime} 30.481^{\prime \prime}$ & $33^{\circ} 51^{\prime} 29.831^{\prime \prime}$ & $33^{\circ} 51^{\prime} 29.855^{\prime \prime}$ & $33^{\circ} 51^{\prime} 28.379^{\prime \prime}$ & $33^{\circ} 51^{\prime} 25.443^{\prime \prime}$ \\
\hline & East longitude & $133^{\circ} 00^{\prime} 51.957^{\prime \prime}$ & $133^{\circ} 00^{\prime} 51.079^{\prime \prime}$ & $133^{\circ} 00^{\prime} 51.076^{\prime \prime}$ & $133^{\circ} 00^{\prime} 51.433^{\prime \prime}$ & $133^{\circ} 00^{\prime} 52.743^{\prime \prime}$ \\
\hline Elevation of borehole top & & $71.11 \mathrm{~m}$ & $71.13 \mathrm{~m}$ & $71.16 \mathrm{~m}$ & $66.93 \mathrm{~m}$ & $74.97 \mathrm{~m}$ \\
\hline Total length of borehole & & $330.00 \mathrm{~m}$ & $180.00 \mathrm{~m}$ & $170.00 \mathrm{~m}$ & $120.00 \mathrm{~m}$ & $80.00 \mathrm{~m}$ \\
\hline Dip angle of borehole & & $82^{\circ}$ & $46^{\circ}$ & $63^{\circ}$ & $40^{\circ}$ & $90^{\circ}$ \\
\hline Direction of borehole & & $187^{\circ}$ & $167^{\circ}$ & $170^{\circ}$ & $172^{\circ}$ & - \\
\hline Cores recovered section & & $\begin{array}{l}55.59- \\
330.00 \mathrm{~m}\end{array}$ & $\begin{array}{l}0.00- \\
180.00 \mathrm{~m}\end{array}$ & $\begin{array}{l}10.00- \\
170.00 \mathrm{~m}\end{array}$ & $\begin{array}{l}20.00- \\
170.00 \mathrm{~m}\end{array}$ & $\begin{array}{l}0.00- \\
80.00 \mathrm{~m}\end{array}$ \\
\hline Drilling method & & Rotary, wireline & Rotary, conventi & & & \\
\hline Drill bit type & & $\mathrm{HQ}$, diamond bit & JIS $\Phi 86 \mathrm{~mm}, \Phi 66$ & n, diamond bit & & \\
\hline
\end{tabular}

Sibson (1977). The orientation of the fault attitude has been determined using borehole televiewer analysis.

\section{Structural features of the MTLTB and MTLAFZ fault zones}

In the trench exposure, there were mudstones of the Cretaceous Izumi Group, fault gouges originating from the Izumi Group, and sand gravels of the Holocene fluvial deposit (Fig. 2 and Additional file 1: Fig. S1). The Kawakami Fault juxtaposed the Izumi Group to the south against fluvial deposits to the north. The fault damage zone, composed of mudstones, was developed at approximately $2 \mathrm{~m}$ or more at the footwall of the Kawakami Fault, and was characterized by a fractured damage zone and partial brecciation. In the fluvial deposits of the hanging wall (Fig. 2, Fd2), some gravels along the main fault exhibited a preferred orientation owing to rotation with the fault movement. The present fluvial deposit (Fd1) unconformably covered the most recent main fault (Fig. 2b), represented by the boundary between the fault gouge (Fig. 2, g1-g3) derived from the Izumi Group and the mixture of gouge and gravel of fluvial deposits (Fig. 2, g4) dipping at $72^{\circ}$ to the north. The trace of the most recent main fault intersected the older fault gouge (Fig. 2, g1-g3) with a thickness of 2-3 m. The most recent main fault had a smooth surface with slightly eastward plunging striations (Fig. 2a). It is suggested that the shear sense indicates the dextral displacement at the outcrop near the trench site (Kubota et al. 2020). The old fault gouge dipped at more than $80^{\circ}$ to the south and was composed of more consolidated material compared to that of the g4 fault gouge. Foliation of the old gouge was partially rounded and discontinuous.

The geological column and composite well logging profiles of H31MTLD-1 and the geological columns of H31MTLD-2, H31MTLP-1, R2MTLD-1, and H31MTLD-3 are shown in Fig. 3. The columnar borehole sections in Fig. 3 were aligned with the MTLTB of each borehole at the same level. The drill core was composed of Sanbagawa metamorphic rocks, two sets of the main fault zone, sandstones and mudstones of the Izumi Group, conglomerates of the Okamura Group, and fluvial deposits, in ascending order. The main fault zone was composed of andesite-dominant breccia, serpentinite-dominant breccia, and mixed breccia. The MTLTB juxtaposed the Sanbagawa metamorphic rocks against the andesite-dominant breccia and had a sharp principal slip zone (PSZ), which was composed of a fault gouge less than a few-centimeters-thick along the geological boundary. The Sanbagawa metamorphic rocks were largely intact except for the rocks surrounding the MTLTB, which had few thin cohesive cataclasites of less than $1.8 \mathrm{~m}$ width within the intact section. The Kawakami Fault juxtaposed the Izumi Group against the andesite-dominant breccia or the Okamura Group and had a sharp PSZ composed of a fault gouge of less than a few-centimeters-thick along the geological boundary. Detailed descriptions of each site are provided below.

Borehole H31MTLD-1 penetrated a total length of $330 \mathrm{~m}$ with a plunge of $82^{\circ}$ to the south. The drill core 


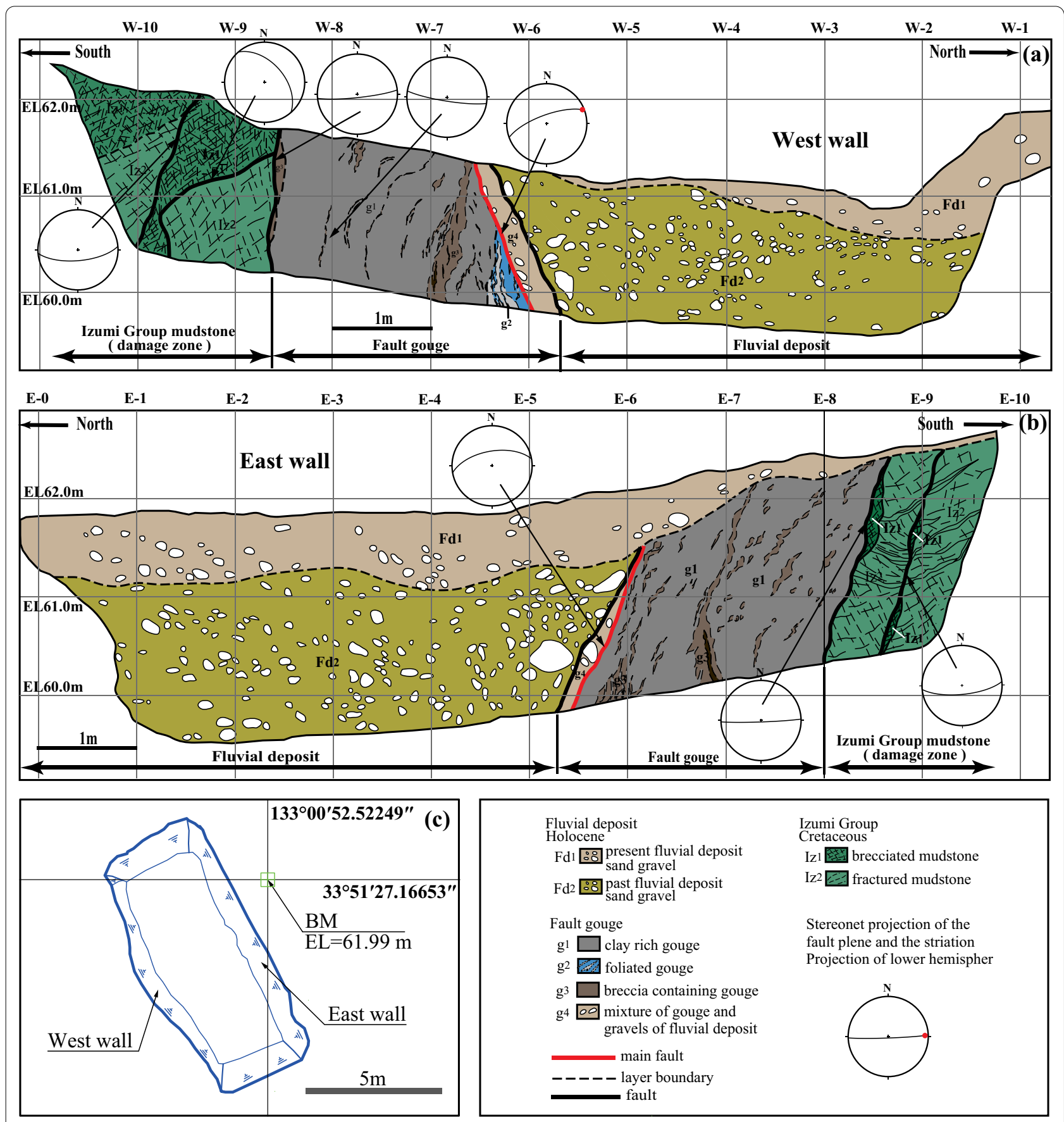

Fig. 2 Logs of the Kawakami Fault on the trench wall (Fig. 1c, loc. 5). a Logs of the west wall, and $\mathbf{b}$ log of the east wall. c The survey map shows a trench site and a benchmark (BM) at the Yuyaguchi site

was composed of Sanbagawa metamorphic rocks, the main fault zone, mudstones and sandstones of the Izumi Group, conglomerates of the Okamura Group and sand gravels of the fluvial deposit, in ascending order. The Sanbagawa metamorphic rocks were divided into upper and lower parts. The upper Sanbagawa metamorphic rocks consisted of pelitic schists and the lower Sanbagawa metamorphic rocks consisted of psammitic schists, siliceous schists, basic schists, and alternating psammitic and siliceous schists. The main identified fault zone in the core samples comprised andesite- and serpentinite-dominant breccias, and mixed breccias composed of fragments 


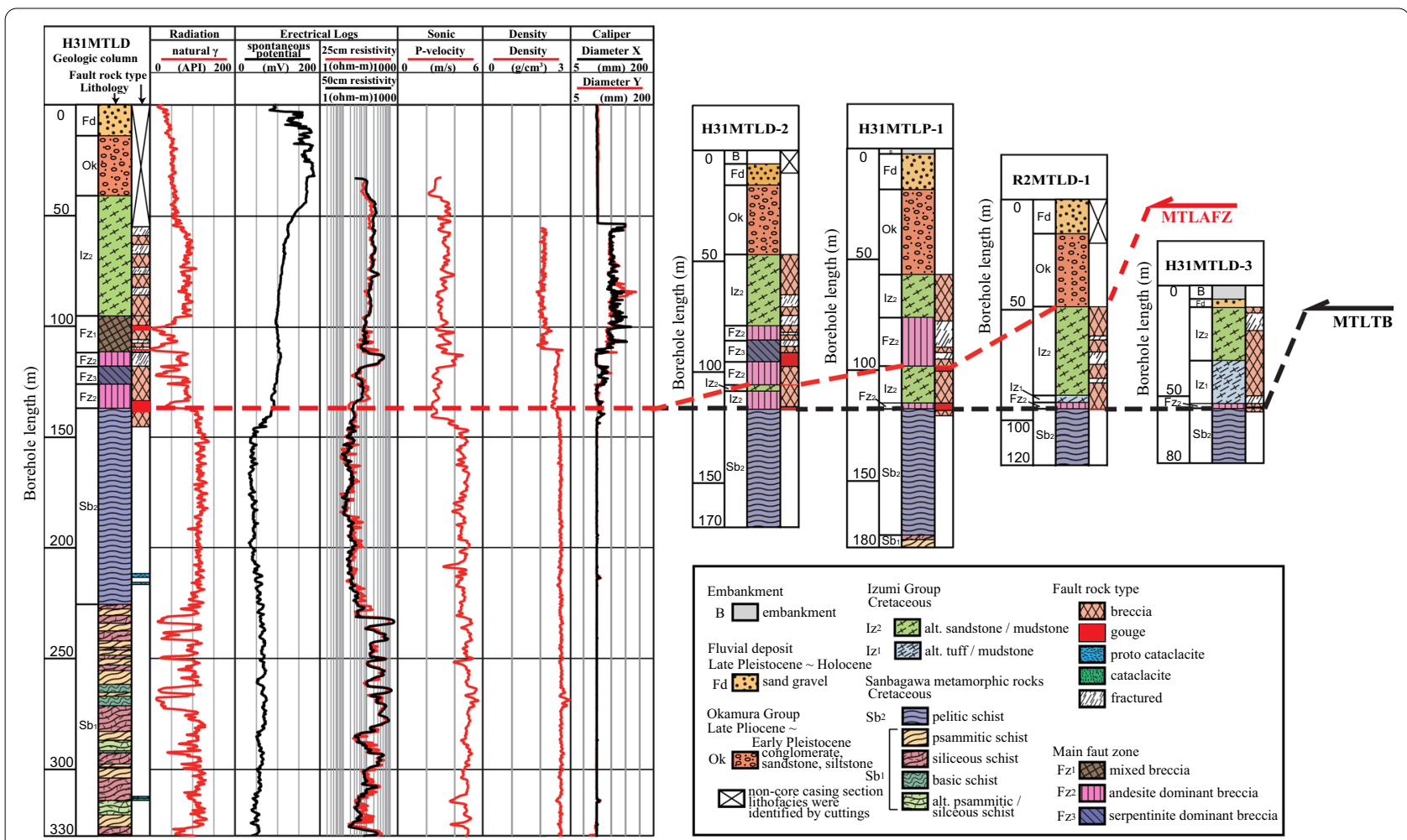

Fig. 3 Geological columns and composite well logging profiles. Diagrams showing the geological columns and composite well logging profiles of H31MTLD-1, and the geological columns of H31MTLD-2, H31MTLP-1, R2MTLD-1, and H31MTLD-3 at the Yuyaguchi site

of sandstones, basic rocks, schists, and andesites in a sheared mudstone matrix. The MTLTB juxtaposed the Sanbagawa metamorphic rocks against the andesitedominant breccia of the main fault zone at $137.03 \mathrm{~m}$; it had a sharp PSZ which was composed of a 4-cm-thick fault gouge along the geological boundary (Additional file 1: Fig. S2a). The dip angle of the PSZ was $30^{\circ}$ to the north, as detected by the acoustic borehole televiewer (Additional file 1: Fig. S3a). The upper boundary of the main fault zone was recognized at $95.25 \mathrm{~m}$; it had an irregular fault surface. The Izumi Group was characterized by a fractured damage zone and partial brecciation. Most parts of the Sanbagawa metamorphic rocks were intact, except for the breccia zone, which was approximately $1.5 \mathrm{~m}$ thick along the MTLTB. Cohesive cataclastic zones less than $1.8 \mathrm{~m}$ thick were found at $211.5 \mathrm{~m}$, $215.57 \mathrm{~m}$, and $312.15 \mathrm{~m}$; they partially had a remnant original schistose structure (Additional file 1: Fig. S4). The borehole-logging analysis was completed in this section. The P-wave velocity was less than $4 \mathrm{~km} / \mathrm{s}$ in the sedimentary rocks of the hanging wall of the MTLTB and was up to $5 \mathrm{~km} / \mathrm{s}$ at the footwall. The observed step changes in the velocities occurred across the MTLTB within a few meters of the core. This contrast in P-wave velocity might be related to differences in lithology and the magnitude of fault damage. The value of the spontaneous potential was higher than $100 \mathrm{mV}$ at the hanging wall and less than $75 \mathrm{mV}$ at the footwall. These high P-wave values and low spontaneous potentials at the footwall were consistent with the results obtained for soft sedimentary and hard metamorphic rocks, respectively. The values of the natural gamma rays and electrical resistivity were relatively stable along the entire borehole, except for the section of the breccia and the alternation zone of the psammitic, silicious, and basic schists. Around the fault zone, the natural gamma ray value was below approximately 100 API, and the electrical resistivity was lower than approximately $150 \Omega \cdot \mathrm{m}$. This might be related to differences in lithology and clay content within the fault damage zone.

Borehole H31MTLD-2 penetrated to a total length of $170 \mathrm{~m}$ with a plunge of $63^{\circ}$ to the south. The drill core was composed of the Sanbagawa metamorphic rocks, two sets of the main fault zone, mudstones and sandstones of the Izumi Group, conglomerates of the Okamura Group, and sand gravels of the fluvial deposit, in ascending order. The Sanbagawa metamorphic rocks were composed of pelitic schists. The Izumi Group was characterized by a fractured damage zone and partial brecciation. The main fault zone was composed of andesite- and serpentinitedominant breccias. The Kawakami Fault juxtaposed the 
mudstones and sandstones of the Izumi Group against the andesite-dominant breccia of the main fault zone at $105.68 \mathrm{~m}$; it had a sharp PSZ consisting of a 3-5 mmthick fault gouge along the geological boundary (Additional file 1: Fig. S2b). The dip angle of the PSZ was $46^{\circ}$ to the north, as detected by the optical borehole televiewer (Additional file 1: Fig. S3b). The upper boundary of the main fault zone was recognized at $79.95 \mathrm{~m}$; it had an irregular fault surface. The MTLTB juxtaposed the Sanbagawa metamorphic rocks against the andesitedominant breccia of the main fault zone at $116.75 \mathrm{~m}$; it had a sharp PSZ consisting of an 8-mm-thick fault gouge along the geological boundary (Additional file 1: Fig. S2c). The dip angle of the PSZ was $38^{\circ}$ to the north, as detected by the optical borehole televiewer (Additional file 1: Fig. S3c). Most parts of the Sanbagawa metamorphic rocks were intact except for the breccia zone, which was approximately $0.3 \mathrm{~m}$ thick along the MTLTB.

Borehole H31MTLP-1 penetrated to a total length of $180 \mathrm{~m}$ with a plunge of $46^{\circ}$ to the south. The drill core was composed of the Sanbagawa metamorphic rocks, two sets of the main fault zone, mudstones and sandstones of the Izumi Group, conglomerates of the Okamura Group, and sand gravels of the fluvial deposit, in ascending order. The Sanbagawa metamorphic rocks in this borehole can be divided into upper and lower parts. The upper part consisted of pelitic schists, and the lower part consisted of psammitic schists and siliceous schists. The Izumi Group was characterized by a fractured damage zone and partial brecciation. The main fault zone was composed of andesite- and serpentinite-dominant breccias. The Kawakami Fault juxtaposed the mudstones and sandstones of the Izumi Group against the andesitedominant breccias of the main fault zone at $100.46 \mathrm{~m}$; it had a sharp PSZ which consisted of a 3-cm-thick fault gouge along the geological boundary. The upper boundary of the main fault zone was recognized at $74.35 \mathrm{~m}$; it had an irregular fault surface. The MTLTB juxtaposed the Sanbagawa metamorphic rocks against the andesitedominant breccias at $117.46 \mathrm{~m}$; it had a sharp PSZ which consisted of a 5-mm-thick fault gouge along the geological boundary. Most parts of the Sanbagawa metamorphic rocks were intact, except for the breccia zone, which was approximately $3 \mathrm{~m}$ thick along the MTLTB.

Borehole R2MTLD-1 penetrated to a total length of $120 \mathrm{~m}$ with a plunge of $40^{\circ}$ to the south. The drill core was composed of the Sanbagawa metamorphic rocks, the main fault zone, mudstones and sandstones of the Izumi Group, conglomerates of the Okamura Group, and sand gravels of the fluvial deposit, in ascending order. The Sanbagawa metamorphic rocks were composed of pelitic schists. The Izumi Group was characterized by a fractured damage zone and partial brecciation. The main fault zone was composed of andesite-dominant breccias. The Kawakami Fault juxtaposed the mudstones and sandstones of the Izumi Group against the conglomerates of the Okamura Group at $48.45 \mathrm{~m}$; it had a sharp PSZ consisting of a few-millimeter-thick fault gouge along the geological boundary (Additional file 1: Fig. S2d). The dip angle of the PSZ was $71^{\circ}$ to the north, as detected by the optical borehole televiewer (Additional file 1: Fig. S3d). The upper boundary of the main fault zone was recognized at $74.35 \mathrm{~m}$; it had an irregular fault surface. Most parts of the Okamura Group were not deformed except for the shear zone, which was approximately $10-\mathrm{cm}$ thick along the Kawakami Fault. The MTLTB juxtaposed the Sanbagawa metamorphic rocks against the andesitedominant breccia of the main fault zone at $94.65 \mathrm{~m}$; it had a sharp PSZ consisting of a 1- to 3-cm-thick fault gouge along the geological boundary (Additional file 1: Fig. S2e). The dip angle of the PSZ was $26^{\circ}$ to the north, as detected by the optical borehole televiewer (Additional file 1: Fig. S3e). Most parts of the Sanbagawa metamorphic rocks were intact except for the breccia zone, which was approximately $0.3 \mathrm{~m}$ thick along the MTLTB.

Borehole H31MTLD-3 penetrated vertically to a total length of $80 \mathrm{~m}$. The drill core was composed of the pelitic schists of the Sanbagawa metamorphic rocks, the main fault zone, the Izumi Group, and sand gravels of the fluvial deposit, in ascending order. The Sanbagawa metamorphic rocks were composed of pelitic schists. The Izumi Group was composed of sandstone, mudstone, and tuff, and was characterized by a fractured damage zone and partial brecciation. The MTLTB juxtaposed the Sanbagawa metamorphic rocks against the andesite-dominant breccias of the main fault zone at $55.28 \mathrm{~m}$; it had a sharp PSZ consisting of a 5-mm-thick fault gouge along the geological boundary (Additional file 1: Fig. S2f). The dip angle of the PSZ was $31^{\circ}$ to the north, as detected the optical borehole televiewer (Additional file 1: Fig. S3f). Most parts of the Sanbagawa metamorphic rocks were intact except for the breccia zone, which was approximately $0.4 \mathrm{~m}$ thick along the MTLTB.

\section{Discussion}

Figure 4 shows the composite geological profile of the MTLTB and the MTLAFZ (Kawakami Fault) constructed using the data obtained from trenching and drilling. The attitudes of the faults were determined from borehole televiewer analyses and trench investigations. The Kawakami Fault was identified as a geological boundary between the fluvial deposit and Izumi Group at the exposed trench. Fault boundaries were also observed between the Okamura Group and the Izumi Group at R2MTLD-1, and between the andesite-dominant breccias and the Izumi Group at H31MTLP-1and 


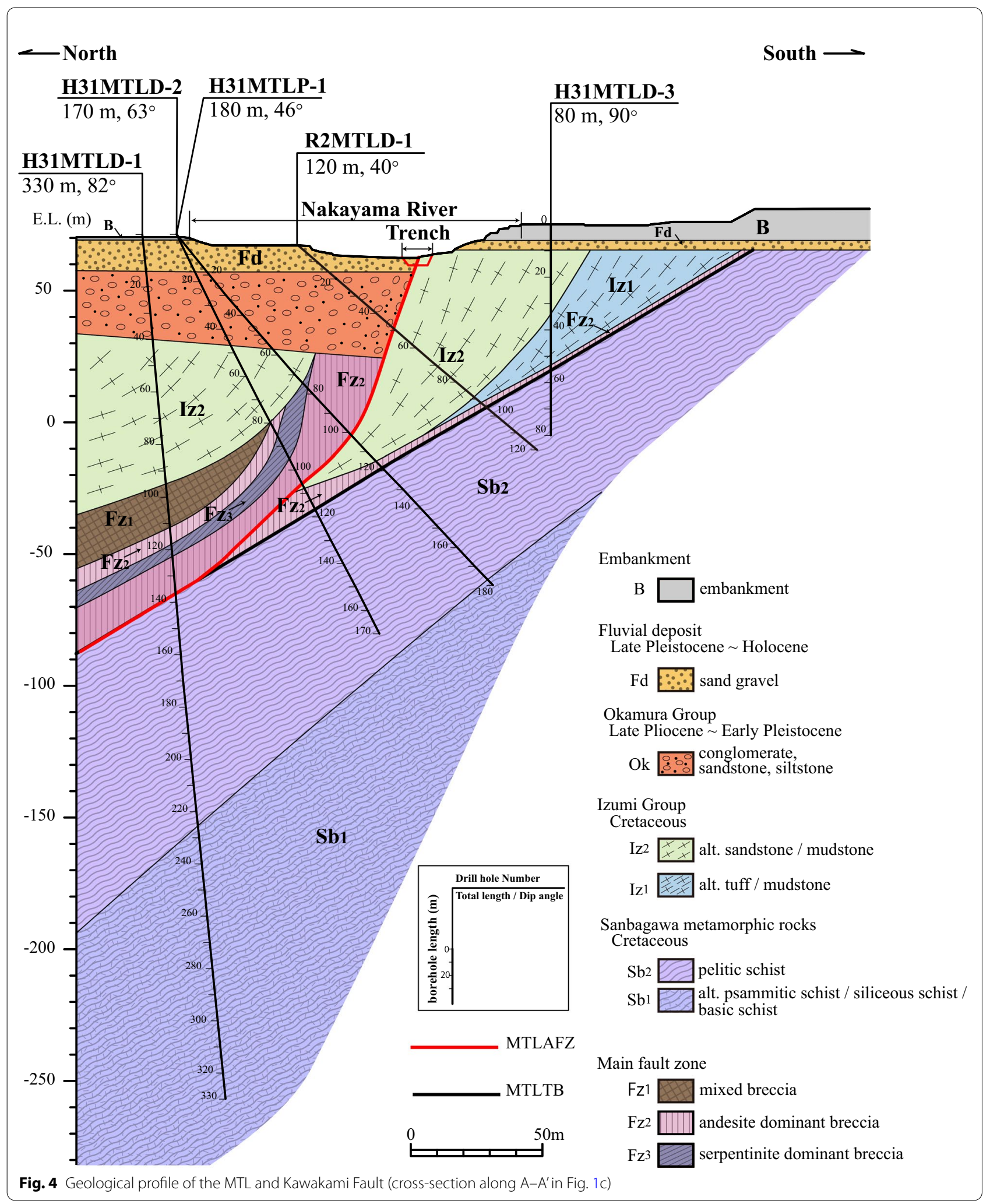


H31MTLD-2. The MTL was identified as the geological boundary between the andesite-dominant breccias and the Sanbagawa metamorphic rocks at all boreholes. The Kawakami Fault and the MTLTB had a sharp PSZ consisting of a fault gouge less than a few-centimetersthick along the geological boundary. These PSZs can be traced along the lower boundary of the main fault zone. The dip angle of the PSZ with the Kawakami Fault was $72^{\circ}$ to the north in the trench exposure, $71^{\circ}$ to the north along R2MTLD- 1 , and $46^{\circ}$ to the north along H31MTLD-2. In H31MTLD-1, the Kawakami Fault converged to the MTLTB, which dips to the north at $30^{\circ}$. The average dip angle of the MTLTB in the study area was estimated to be approximately $30^{\circ}$ to the north (Additional file 1: Fig. S5). As another possible trace of the Kawakami Fault, the fault passed from the trench exposure to the upper boundary of the main fault zone and rooted to the MTLTB. However, there were no faults in the Okamura Group in the section of the predicted Kawakami Fault in R2MTLD-1. Therefore, it appears that the upper boundary fault of the main fault zone was eroded by deposition of the Okamura Group. The Kawakami Fault displaced the Izumi Group and andesite-dominant breccias upward toward the south. In addition, the Okamura Group half-graben deposits covered the hanging wall of the Kawakami Fault. This structure might reflect changes in the motion of the reverse fault displacement caused by compression and the subsequent normal displacement associated with an extension. The shear sense of the Kawakami Fault reflected that the latest shear sense was dextral and that of the cataclasite was sinistral-reverse (Kubota et al. 2020). At the trench, the latest fault plane of the ENEWSW trending Kawakami Fault dipped at approximately $72^{\circ}$ to the north, and the striations on the fault plane dipped slightly eastward (Fig. 2a). Therefore, the latest displacement was considered to accommodate a normal displacement, which is consistent with the deposition of the Okamura Group. It is suggested that the Kawakami fault was originally formed as a non-vertical reverse fault, and subsequent dextral strike-slip displacement occurred along the same fault plane. In this study area, previous seismic reflection surveys indicated a clear reflector dipping $30^{\circ}$ to the north (Shigei et al. 2014). This is consistent with the north-dipping MTLTB, which juxtaposed the Izumi Group against the Sanbagawa metamorphic rocks. It was observed that most MTLAFZ segments run subparallel to each other for a few kilometers north of the MTLTB. Our finding that the high-angle MTLAFZ converges to the lowangle MTLTB at shallow depths, is consistent with the features observed in western Shikoku.
In this study, a combination of paleoseismic trenching and scientific drilling surveys confirmed that the high-angle MTLAFZ has a listric non-vertical fault geometry. The MTLAFZ can be traced at the surface, from where it converges to the low-angle (approximately $30^{\circ}$ ) northward-dipping MTLTB at approximately $140 \mathrm{~m}$ depth and approximately $100 \mathrm{~m}$ north of the trace of the Kawakami Fault. The listric non-vertical geometry of the active strike-slip MTLAFZ and its continuation in depth along the MTLTB indicate that the fault is poorly orientated with respect to the direction of the maximum horizontal stress (Sato et al. 2015), thereby implying that the fault must be weak at depth (Sibson 1990, 2020). Seismic reflection data have revealed reflectors associated with the MTLTB fault zone at larger depths (Ito et al. 1996, 2009; Tsutsumi et al. 2007; Sato et al. 2015). In a regional seismic study (Ito et al. 2009), the MTLTB was imaged as a band of high-amplitude reflector segments cutting through the entire upper crust and dipping northward at $35^{\circ}$. Crustal tomography beneath Shikoku and the Kii Peninsula (Gupta et al. 2009) indicates that the MTLTB is characterized by anomalous delay times coinciding with a low-seismic-wave speed zone in the upper crust. A localized reduction in velocity of $2-6 \%$ is broadly consistent with a moderately northward-dipping fault zone over a length of $300-350 \mathrm{~km}$ that penetrates to a depth of approximately $20 \mathrm{~km}$ (Gupta et al. 2009). Faulted rocks might have a low seismic velocity because of the clay-rich gouge, high crack density, and high pore fluid pressure. The combination of low seismic velocity and low resistivity $(<50 \Omega \cdot \mathrm{m})$ at a depth of $15 \mathrm{~km}$ (Ikeda et al. 2013) suggests interconnected pore fluids at pressures approaching lithostatic and imply relatively low effective stress. Based on geodetic data along with the best-fitting fault plane model, the current configuration of the MTLTB appears to be locked with a dip of $35^{\circ}-45^{\circ}$ in the northward direction. The boundary appears to be $100 \%$ locked at a depth of $15 \mathrm{~km}$ with a steady slip of $5 \mathrm{~mm} / \mathrm{yr}$ at larger depths (Tabei et al. 2002).

The Wairarapa Fault, New Zealand, is a similar poorly oriented strike-slip fault exhibiting a listric geometry (Darby and Beanland 1992; Darby and Beavan 2001; Henrys et al. 2013). The association of high fluid pressures and long-term fault weakness with geodetic locking at the Wairarapa Fault implies that the properties of local materials might have played a significant role in determining the behavior of the localized fault slips (Kurashimo et al. 2015). For example, slip on a nonoptimally oriented fault plan may occur if the work 
required to generate a new fault is greater than the work against friction on a pre-existing surface. Given the contrasting physical properties and localized shear zones observed from the logs of the borehole televiewer across the MTLTB and MTLAFZ faults, we speculate that local frictional forces and other material properties might also be important parameters for promoting locking and failure in future large earthquake ruptures along the Shikoku segment of the MTLAFZ.

The Keicho earthquake in 1596 (Ikeda et al. 2014, 2019 ) is thought to have ruptured multiple segments of the MTLAFZ, indicating that weak fault segments and low shear stress patches did not impede the dynamic rupture of the Keicho earthquake. Thus, high-magnitude earthquakes with rupture dimensions of several hundred kilometers remain a realistic future scenario along the MTLTB and MTLAFZ.

\section{Conclusions}

Based on the shallow trench and borehole data collected at the Yuyaguchi site across the MTL, situated $10 \mathrm{~km}$ southwest of Nyugawa in western Shikoku, we were able to confirm that the Kawakami Fault (MTLAFZ) roots to the MTLTB at approximately $140 \mathrm{~m}$ beneath the surface. We infer that the MTLTB at this locality dips at approximately $30^{\circ}$ to the north. The trace of the high-angle $\left(>70^{\circ}\right)$ active MTLAFZ fault observed at the trench site was considered to be limited to depths of less than $140 \mathrm{~m}$ below the surface. This suggests that the main MTLTB fault, which divides the island-arc crust, forms a low-angle (approximately $30^{\circ}$ ) northward-dipping structure extending to the base of the crust. These results are consistent with those of other studies conducted on this segment of the MTLTB (Ito et al. 1996). Moreover, the MTLTB extends further east along the Kii Peninsula (Sato et al. 2015). The Kawakami fault was originally formed as a non-vertical reverse fault, and subsequent dextral strike-slip displacement has occurred along the same fault plane. Our results support previous studies that indicate that the MTLTB, although poorly oriented with respect to the regional stress field, is capable of rupturing given its sufficiently weak interface, and the properties of local materials might play a significant role in determining slip behavior. Knowledge of the dip angle of the MTL fault plane is expected to help in evaluating earthquake rupture scenarios for hazard modeling and assessment. In a future study, we will clarify the deformation conditions of fault rocks by conducting petrological and chemical analyses. We will also clarify the evolution of the MTL from microstructural analysis.
Abbreviations

MTL: Median Tectonic Line; MTLAFZ: Median Tectonic Line active fault zone; MTLTB: Median Tectonic Line terrane boundary; PSZ: Principal slip zone.

\section{Supplementary Information}

The online version contains supplementary material available at https://doi. org/10.1186/s40623-021-01526-w.

Additional file 1: A file containing three supplemental figures: Figures S1, S2, S3, S4, and S5.

\section{Acknowledgements}

We thank S. Shibutani, T. Takahashi, Y. Fujimoto, and A. Tanase of Chi-ken Sogo Consultants Co., Ltd. for operating the drilling and trench investigations over the last three years. The manuscript has been greatly improved from the comments of Editor Dr. Stuart Henrys and the reviewer Dr. Norio Shigematsu. We thank Dr. M. Komatsu, former president of Ehime University, for insightful discussions.

\section{Authors' contributions}

MM conducted trench and drilling surveys. AS conducted the drilling survey. Both authors contributed to the data analysis, interpretation, and preparation of the manuscript. Both authors read and approved the final manuscript.

Funding

Not applicable to this study.

\section{Availability of data and materials}

Project reports including trench photos, trench logs, drill core photos, drill core descriptions, and geophysical logs will be available at the National Diet Library, Japan, after all related manuscripts are published.

\section{Declarations}

Ethics approval and consent to participate

Not applicable to this study.

Consent for publication

Not applicable to this study.

Competing interests

The authors declare that they have no competing interests.

\section{Author details}

${ }^{1}$ Regulatory Standard and Research Department, Secretariat of Nuclear Regulation Authority (S/NRA/R), 1-9-9 Roppongi, Minato-ku, Tokyo 106-8450, Japan. ${ }^{2}$ Graduate School of Sciences and Technology for Innovation, Yamaguchi University, 1677-1, Yoshida, Yamaguchi 753-8511, Japan.

Received: 29 April 2021 Accepted: 5 October 2021

Published online: 21 October 2021

\section{References}

Aoya M, Noda A, Mizuno K, Mizukami T, Miyachi Y, Matsuura H, Endo S, Toshimitsu S, Aoki M (2013) Geology of the Niihama district (in Japanese with English abstract). Quadrangle Series, 1:50,000 Geological Survey of Japan:1-181

Atwater T (1970) Implications of plate tectonics for the cenozoic tectonic evolution of western North America. Geol Soc Am Bull 81 (12):3513-3536. https://doi.org/10.1130/0016-7606(1970)81[3513:IOPTFT]2.0.CO;2

Darby DJ, Beanland S (1992) Possible source models for the 1855 Wairarapa earthquake, New Zealand. J Geophys Res 97(B9):12375-312389. https:// doi.org/10.1029/92jb00567 
Darby D, Beavan J (2001) Evidence from GPS measurements for contemporary interplate coupling on the southern Hikurangi subduction thrust and for partitioning of strain in the upper plate. J Geophys Res Solid Earth 106(B12):30881-30891. https://doi.org/10.1029/2000jb000023

Geological Survey of Japan (2017) Seamless digital geological map of Japan 1:200,000 V2 (update date, April 629,2020 ). Geological Survey of Japan National Institute of Advanced Industrial Science and Technology. Doi: https://doi.org/10.1016/j.quaint.2017.12.013

Goto H (2018) Late quaternary slip rates and vectors on the Median Tectonic Line active fault zone in eastern Shikoku, southwest Japan. Quat Int 471:267-277. https://doi.org/10.1016/j.quaint.2017.12.013

Goto H, Nakata T (2000) Detailed distribution of active faults along the Median Tectonic Line in Shikoku. Spec Publi Res Cent Reg Geogr Hiroshima Univ 35:144p

Goto H, Niwa S, Nakata T, Okada A, Tsutsumi H (1998) Active fault map in urban area, Matsuyama, vol D.1-No.355, scale 1:25,000 Geospatial Information Authority of Japan,

Goto H, Nakata T, Tsutsumi H, Okumura K, Imaizumi T, Nakamura T, Watanabe $T$ (2001) The latest surface-faulting events on the Median Tectonic Line in Shikoku, Southwest Japan, based on mini- trenching and geoslicer studies (in Japanese with English abstract). J Seimol Soc Jpn 2nd Ser 53(3):205-219. https://doi.org/10.4294/zisin1948.53.3_205

Gupta S, Zhao D, Ikeda M, Ueki S, Rai SS (2009) Crustal tomography under the Median Tectonic Line in Southwest Japan using P and PmP data. J Asian Earth Sci 35(5):377-390. https://doi.org/10.1016/j.jseaes.2009.01.004

Henrys S, Wech A, Sutherland R, Stern T, Savage M, Sato H, Mochizuki K, Iwasaki T, Okaya D, Seward A, Tozer B, Townend J, Kurashimo E, lidaka T, Ishiyama T (2013) SAHKE geophysical transect reveals crustal and subduction zone structure at the southern Hikurangi margin, New Zealand. Geochem Geophys Geosyst 14(7):2063-2083. https://doi.org/10.1002/ggge.20136

Ichikawa K (1980) Geohistory of the Median Tectonic Line of Southwest Japan. Mem Geol Soc Jpn 18:187-212

Ikeda M, Goto H, Tsutsumi H, Tsuyuguchi K, Ohno Y, Nishizaka N, Kobayashi S (2012) Holocene faulting history of the lyo Fault, part of the Median Tectonic Line active fault system in northwest Shikoku, southwest Japan (in Japanese with English abstract). J Geol Soc Jpn 118(4):220-235. https:// doi.org/10.5575/geosoc.2011.0032

Ikeda M, Kato S, Nishizaka N, Ohno Y, Matsuo K, Kishimoto M (2013) Magnetotelluric imaging of the Median Tectonic Line in western Shikoku, southwest Japan: Implications of the fault-related low-resistivity zone. Tectonophysics 601:78-86. https://doi.org/10.1016/j.tecto.2013.04.026

Ikeda M, Toda S, Onishi K, Nishizaka N, Suzuki S (2019) The 1596 Keicho earthquake, a 5-Day, 300-km-long sequential rupture event in the Median Tectonic Line fault zone, Southwestern Japan. J Geophys Res Solid Earth 124(8):8376-8403. https://doi.org/10.1029/2018JB017264

Ikeda M, Tsutsumi H, Goto H, Nishizaka N, Ohno Y, Yanagida M (2014) Late Holocene faulting along the Kawakami fault, an active segment of the Median Tectonic Line, southwest Japan (in Japanese with English abstract). Active Fault Res 40:1-18. https://doi.org/10.11462/afr.2014.40_1

Ito T, Ikawa T, Yamakita S, Maeda T (1996) Gently north-dipping Median Tectonic Line (MTL) revealed by recent seismic reflection studies, southwest Japan. Tectonophysics 264(1-4):51-63. https://doi.org/10.1016/s00401951(96)00117-5

Ito T, Kojima Y, Kodaira S, Sato H, Kaneda Y, Iwasaki T, Kurashimo E, Tsumura N, Fujiwara A, Miyauchi T, Hirata N, Harder S, Miller K, Murata A, Yamakita S, Onishi M, Abe S, Sato T, Ikawa T (2009) Crustal structure of southwest Japan, revealed by the integrated seismic experiment Southwest Japan 2002. Tectonophysics 472(1-4):124-134. https://doi.org/10.1016/j.tecto. 2008.05.013

Iwata T, Asano K, Sekiguchi H, Yamada K, Suehiro M (2020) Seismic reflection surveys and borehole experiments at the Median Tectonic Line (Wakayama Pref. Area) (in Japanese with English abstract). DPRI Ann 63B:25-45

Kobayashi T (1941) The Sakawa orogenic cycle and its bearing on the origin of the Japanese Islands. J Fac Sci Imp Univ Tokyo, Sec 2(5):219-578

Kubota Y, Takeshita T, Yagi K, Itaya T (2020) Kinematic analyses and radiometric dating of the large-scale paleogene two-phase faulting along the Median Tectonic Line, Southwest Japan. Tectonics. https://doi.org/10. 1029/2018tc005372

Kubota Y, Takeshita T (2007) Paleocene large-scale normal faulting along the Median Tectonic Line, western Shikoku. Japan Isl Arc 17(1):129-151. https://doi.org/10.1111/j.1440-1738.2007.00607.x
Kurashimo E, Henrys S, Sato H, Iwasaki T, Okaya D, Sutherland R, Stern T, lidaka T, Ishiyama T, Savage M (2015) SAHKE seismic-scatter imaging of subduction beneath Wellington, North Island, New Zealand. Geophys Res Lett 42(9):3240-3247. https://doi.org/10.1002/2015GL063230

Lawson AC (1895) Sketch of the geology of the San Francisco peninsula, California. US Geol Surv Annu Rep 15:399-476

Little TA, Van Dissen R, Schermer E, Carne R (2009) Late Holocene surface ruptures on the southern Wairarapa fault, New Zealand: link between earthquakes and the uplifting of beach ridges on a rocky coast. Lithosphere 1(1):4-28. https://doi.org/10.1130/L7.1

Nagai K, Kondo M (1972) Median dislocation line of the lower Kamo-gawa (River) area, Saijo City (in Japanese with English abstract). Mem Ehime Univ Nat Sci Ser D (ear Sci) 7:8-12

Nakata T, Goto H, Okada A, Tsutsumi H, Niwa S (1998) Active fault map in urban area, Saijyo, vol D.1-No.355, scale 1:25,000 Geospatial Information Authority of Japan

Naumann E (1886) Ueber meine topographische und geologische Landesaufnahme Japans. Verhandlungen des sechsten deutschen Geographentages zu Dresden:14-28

Nishimura T, Yokota Y, Tadokoro K, Ochi T (2018) Strain partitioning and interplate coupling along the northern margin of the Philippine Sea plate, estimated from Global Navigation Satellite System and Global Positioning System-Acoustic data. Geosphere 14(2):535-551. https://doi.org/10.1130/ GES01529.1

Okada A (1970) Fault topography and rate of faulting along the Median Tectonic Line in the drainage basin of the River Yoshino, Northeastern Shikoku, Japan (in Japanese with English abstract). Geogr Rev Jpn 43(1):1-21. https://doi.org/10.4157/grj.43.1

Okada A (1973) Quaternary faulting along the Median Tectonic Line in the central part of Shikoku (in Japanese with English abstract). Geogr Rev Jpn 46(5):295-322. https://doi.org/10.4157/gri.46.295

Okada A, Tsutsumi H (1997) Holocene activity of the Chichio fault, the Median Tectonic Line active fault system, southwest Japan, based on trenching studies (in Japanese with English abstract). J Geogr 106(5):644-659. https://doi.org/10.5026/jgeography.106.5_644

Research Group for Active Faults of Japan (1991) Active Faults in Japan: sheet maps and inventories (revised edition). University of Tokyo Press, Tokyo

Rodgers DW, Little TA (2006) World's largest coseismic strike-slip offset: The 1855 rupture of the Wairarapa Fault, New Zealand, and implications for displacement/length scaling of continental earthquakes. J Geophys Res Solid Earth. https://doi.org/10.1029/2005JB004065

Sato H, Kato N, Abe S, Van Horne A, Takeda T (2015) Reactivation of an old plate interface as a strike-slip fault in a slip-partitioned system: Median Tectonic Line, SW Japan. Tectonophysics 644-645:58-67. https://doi.org/ 10.1016/j.tecto.2014.12.020

Shigei Y, Tsuji T, Matsuoka T, Ikeda M, Nishizaka N, Ishikawa Y (2014) Seismicderived quality factor for lithology classification around the Median Tectonic Line (in Japanese with English abstract). J Soc Mater Sci Jpn 63(3):250-257. https://doi.org/10.2472/jsms.63.250

Shigematsu N, Fujimoto K, Tanaka N, Furuya N, Mori H, Wallis S (2012) Internal structure of the Median Tectonic Line fault zone, SW Japan, revealed by borehole analysis. Tectonophysics 532-535:103-118. https://doi.org/10. 1016/j.tecto.2012.01.024

Sibson RH (1977) Fault rocks and fault mechanisms. J Geol Soc 133(3):191-213. https://doi.org/10.1144/gsjgs.133.3.0191

Sibson RH (2020) Preparation zones for large crustal earthquakes consequent on fault-valve action. Earth Planets Space 72(1):31. https://doi.org/10. 1186/s40623-020-01153-x

Sibson RH (1990) Rupture nucleation on unfavourably oriented faults. Bull Seismol Soc Am 80(6A):1580-1604

Stein RS, Barka AA, Dieterich JH (1997) Progressive failure on the North Anatolian fault since 1939 by earthquake stress triggering. Geophys J Int 128(3):594-604. https://doi.org/10.1111/j.1365-246X.1997.tb05321.x

Tabei T, Hashimoto M, Miyazaki S, Hirahara K, Kimata F, Matsushima T, Tanaka T, Eguchi Y, Takaya T, Hoso Y, Ohya F, Kato T (2002) Subsurface structure and faulting of the Median Tectonic Line, southwest Japan inferred from GPS velocity field. Earth Planets Space 54(11):1065-1070. https://doi.org/10. 1186/BF03353303

Takagi H, Shibata K (1992) K-Ar dating of fault gouge: examples along the Median Tectonic Line (in Japanese with English abstract). Mem Geol Soc Jpn 40:31-38 
Takahashi J (1992) Faulting history of the Median Tectonic Line in Ehime Prefecture (in Japanese with English abstract). Mem Geol Soc Jpn 40:99-112

Tazaki K, Takahashi J, Itaya T, Grapes RH, Kashima N (1990) K-Ar ages of the andesites intruding along the Median Tectonic Line in northwestern Shikoku, Japan (in Japanese with English abstract). J Min Petr Econ Geol 85(4):155-160. https://doi.org/10.2465/ganko.85.155

Tsutsumi H, Okada A (1996) Segmentation and Holocene surface faulting on the Median Tectonic Line, southwest Japan. J Geophys Res Solid Earth 101(B3):5855-5871. https://doi.org/10.1029/95JB01913

Tsutsumi H, Okada A, Nakata T, Ando M (1992) Near surface structure and Holocene movements on the Okamura fault, an active segment of the Median Tectonic Line in central Shikoku : a case study of the 1988 spring trench survey (in Japanese with English abstract). Mem Geol Soc Jpn 40:113-127

Tsutsumi H, Toda S, Imamura T, Ishiyama T, Kawamura T, Sato H, Miyauchi T, Kato H, Kumamoto T, Takeda A, Yamamoto S (2007) Seismic reflection surveys across the Median Tectonic Line active fault zone in Niihama City, Ehime Prefecture and Awa City, Tokushima Prefecture (in Japanese with English abstract). Bull Earthq Res Inst Univ Tokyo 82(1):105-117
Tsutsumi H, Okada A, Nakata T, Goto H, Niwa S (1998) Active fault map in urban area, Niihama, vol D.1-No.355, scale 1:25,000 Geospatial Information Authority of Japan

Walcott RI (1998) Modes of oblique compression: Late cenozoic tectonics of the South Island of New Zealand. Rev Geophys 36(1):1-26. https://doi. org/10.1029/97RG03084

Wellman HW, Willett RW (1942) The geology of the west coast from abut head to milford sound: part 1. Trans Proc Royal Soc N Z 71(6):282-306. https:// doi.org/10.1017/S0016756800076494

Yoshikawa S, Iwasaki Y, Ikawa T, Yokota H (1992) Geological structure of the MTL in west Wakayama by reflection seismic study (in Japanese with English abstract). Mem Geol Soc Jpn 40:177-186

\section{Publisher's Note}

Springer Nature remains neutral with regard to jurisdictional claims in published maps and institutional affiliations.

\section{Submit your manuscript to a SpringerOpen ${ }^{\circ}$ journal and benefit from:}

- Convenient online submission

- Rigorous peer review

- Open access: articles freely available online

- High visibility within the field

- Retaining the copyright to your article

Submit your next manuscript at $\boldsymbol{\nabla}$ springeropen.com 